\title{
The Application of the Task-Based Teaching Method in Business Japanese Teaching
}

\author{
Jiadong Wang \\ Foreign Language School \\ Shandong Jiaotong University(Changqing Campus) \\ Jinan,China \\ hancangyi140@126.com
}

\begin{abstract}
The teaching of business Japanese has gone through decades of development. The development is dramatic both in major construction and enrolment scale. In the meantime, there have been a lot of problems that need to be resolved. In order to improve the teaching of business Japanese, this article studies the application of the Task-based teaching method to the teaching of business Japanese. This article firstly analyzes the implication of the Task-based teaching method and discusses the advantage of the Task-based teaching method in the teaching of Japanese. Then the present situation of business Japanese teaching is analyzed, and finally the strategies of Task-based business Japanese teaching are put forward.
\end{abstract}

Keywords-task-based teaching method; business Japanese; application in practice

\section{TASK-BASED TEACHING METHOD}

\section{A. Definition of Task-based Teaching Method}

The task-based teaching method has been developing since the 1980's and has been taken widely as a foreign language teaching method in applied linguistics and foreign language teaching. It refers to teaching in the form of tasks. In the process of performing a task, it gives full play of learners' cognitive ability during their participation, experience, interaction, communication and co-working with each other. According to their resources of the target language, learners will perceive, learn and use the language in practice. This method shows advanced teaching ideas and is an effective foreign language teaching method worth further application.

\section{B. The Advantages of Task-based Teaching Method}

After a long-time of practicing and summarizing, Chinese educators summed up the advantages of task-based teaching method as follows,

- It helps to raise students' interest in study to design and finish various activities according to the specific major.

- It contributes to cultivate students' comprehensive ability of language application to combine language knowledge and skills.

- It gives play to students' subjective initiative and encourages the students to participate in language communication and to acquire language and related knowledge. It also provides opportunities for students' innovation ability.
- Most of the tasks need co-working in group and everybody has their own task, which cultivates students' ability of collaboration and sense of responsibility.

- The designed activities cover a wide range of content and information. This helps to broaden students' scope of knowledge.

- Students learn in tasks, and then they can complete tasks better. These activities foster students' ability of interpersonal communication, thinking, making decisions and their adaptability to changes. Thus it is good for their integrated development.

- With the enlightenment and guidance of teachers, every student has the opportunity to think independently and positively participe in the activities, which keeps students enthusiastic for study and forms favorable learning habits.

\section{FEATURES AND PROBLEMS OF THE TEACHING OF BUSINESS JAPANESE}

\section{A. The Content of Business Japanese Teaching}

Till now, there is no precise definition for business Japanese in academic circles.But the common ground is that business Japanese is different from previous economic trade Japanese, and it is a comprehensive inter-discipline. It has a wider scope than economic trade Japanese and includes the knowledge of Japanese linguistics, economics and trade and so on. It has evolved from merchandise exports and imports to management, service, law, finance and accounting, IT, etc. The features of business Japanese include practicability, applicability, and occupational.

\section{B. Training Objective of Business Japanese Talents}

Synthesizing the opinions of domestic scholars in related fields, it is easy to find that the competence of business Japanese comprises three aspects which are applying ability, business competence and the ability of intercultural communication as follows.

- The ability of applying the knowledge of business Japanese-C The basic ability of business Japanese talents is Japanese. About listening, users of business Japanese have to understand conversations among company staff, presentations at meetings, and discourses of Japanese clients. As for speaking, the requirements mainly include expressing their own 
intentions clearly, conveying the internal instructions of the organization and clients' requirements, and negotiating with those out of the organization fluently. The requirements of reading refer to understand business documents, proposals, contracts and economic news. For writing, it means to write business letters, documents, and even contracts in right vocabulary and literary forms. Translating requires the users to inter-translate undisputable business letters, documents and contracts, etc.

- Business competence-Business competence can be divided into business knowledge and the ability of applying it in work. The former one refers to the knowledge related to business, including the knowledge of economic management, service, and IT, such as the basic theoretical knowledge of international business, Japanese business convention, knowledge of economic, trade and finance, insurance and public relation, marketing management, etc. Besides, it also involves some laws and regulations, such as the economic law, the labor law, WTO principles, etc, and other related knowledge, such as the business communication means (E-mail, blog, etc.) based on networking.

- The ability of intercultural communication-—The ability of intercultural communication comprises inter-culture business awareness and applicable linguistic and non-linguistic communicative competence. As a worker in a foreign company, it is necessary to have inter-cultural business awareness which means the awareness of commercial people to understand and to make appropriate reactions to cultural difference.

\section{Problems in Present Business Japanese Teaching}

- Limited resources of business Japanese teacher- - The teachers are decisive in business Japanese teaching. In fact, most of colleges and universities do not have enough excellent business Japanese teachers. A majority of the teachers are those who switched to this course from others with the background of conventional Japanese teaching, so they do not have the experience of business practice. These lead to serious impact on business Japanese teaching.

- Curriculum-Business Japanese teaching is the organic combination of language and business courses. But in fact, the teaching methods in many colleges and universities did not yield much. As far as the author knows, the first two years in many colleges and universities focus on basic language knowledge, and centers on business knowledge in the last two years. Business Japanese teaching covers a wide range of subjects, but these subjects and masses of class make most of the students tired, which results in the separation of Japanese and business in students' knowledge structure. And even the business subjects are disjoined from each other, let alone using this knowledge flexibly in real work.

- $\quad$ Laggard model of teaching-_-The most important is the method of interpretation. This does not conform to the features of business Japanese which includes practicability, applicability and occupational. The emphases are to cultivate students' ability of autonomously learning and to improve their ability of knowledge conversion, information processing and team-work.

\section{THE APPLICATION OF THE TASK-BASED TEACHING METHOD IN BUSINESS JAPANESE TEACHING}

\section{A. Task and Practice}

Here is an attempt to apply task-based teaching method in business Japanese, taking the course of "Business Japanese Interpretation" as an example.

Firstly, different tasks have to be designed in accordance with the schedule and complexity of this course. There are some principles in designing the tasks: students can use the knowledge they have learned; they are interested; the task should help students build self-confidence, enhance their ability of autonomous study and improve their awareness and ability of teamwork.

Secondly, teachers divide students into groups based on students' wishes and pay attention to the collocation. Generally, there are 5 students in each group. To make sure that tasks can be completed in a timely manner, students with good reports and ability should be grouped with those who are relatively poor in these aspects so as to help the weaker ones.

The next step is to distribute the tasks to each group before class, such as an opening speech of a Japanese company or a signing ceremony of China-Japan sister cities. Then it comes to break down the tasks. One student searches for and records frequently used vocabulary and expressions needed in the task of his or her group. One or two student(s) make(s) further research on the background of relevant content in the scenario. One or two student(s) do(es) a full investigation analysis and preparation of possible business knowledge used in the interpretation. Then the members of a group have to communicate the knowledge they get for the task with each other.

In class, the teacher plays the original recording on multimedia courseware or tape recorder (sentence by sentence or paragraph by paragraph). And the members translate the sentence or paragraph one by one. Meanwhile, other members in the group can help the student who is interpreting to take notes and look up for relevant knowledge. Of course, the interpretation will be recorded.

In the end, it comes to evaluation. Every student has to evaluate his or her own work. They have to reconsider and confirm their interpretation and put forward suggestions for correction. These enable the students to realize their gains and shortcomings. After that, other members assess his or her interpretation in terms of understanding of business knowledge, vocabulary, grammar, expressions, pronunciation and intonation, etc. and put forward suggestions for correction if necessary. Finally, the teacher shows students the correct translation of the original text, makes comprehensive assessment of students' interpretation, points out problems emerging in the task and comes up with solving strategies to help the students overcome difficulties in later assignment. 


\section{B. Summary of the Practice}

After a period of practice, author finds that the task-based teaching method has favorable effects.

- Students are task-driven and will study, do some research and understand relevant business knowledge spontaneously. They learn better in this way than listening to teachers' speech only.

- Their listening ability and stenographic aptitude are improved significantly. Thus the task-based teaching method promotes students' ability of dealing with business interpretation.

- Significant improvement also happens in vocabulary and expression. Because of the specificity of business Japanese, it is impossible to have every involved knowledge point prepared. And this often happens in real work. After practice, students do not feel as bewildered in these kind of cases as they did. Instead, they will explain and state the knowledge and materials they have to acquire under standing.

- The awareness of teamwork is enhanced. The amount of group-work increases. Students have to share their materials and resources and support each other to complete the assignments. Learning and working are no longer individual behaviors.

There are also some problems emerging after a long time of practice. For example, heavy preparatory workload takes too much effort for the students which may conflict with other courses and break deadlines. Teaching facilities and conditions are also in question.

\section{CONCLUSION}

What has to be noticed is that, compared with conventional Japanese teaching, business Japanese teaching has its own special characteristics and regularities. Students are required to have a certain ability of Japanese, business affairs, and intercultural communication. In this method, students are the subject. They learn and acquire language and business knowledge, and practice understanding and solving problems. Teachers have to update their teaching ideas. They are supposed to respect the dominant position of students, and pay attention to students' individual development and sense of team identity.

\section{References}

[1] Gao Weihong, "The application of the project teaching method inteaching, occupation, "vol. 32, pp. 168-169,2011.

[2] Yan Hongjun, "The analysisi and cultivation of business Japaness competence in business Japaness major," career horizon, vol. 6, pp.84 85,2010

[3] Yan Hongjun, "The definition of business Japaness competence,"Nihongo No Gakushu To Kenkyu, vol. 3, pp. 60-66,2011.

[4] Zhou Linjuan,Pan Youfang, "The demand of business talents in China and Japan and the reform in business Japaness teaching," Nihongo No Gakushu To Kenkyu,vol.2,pp.118-122,2009

[5] Tang Shouyao, "The change of the teachers' role in Task-based teaching process",Journal of Gansu Lianhe University(Natural Sciences),vol.25,pp.57-58,2010.
[6] Wang Lin, "The Current Status of Business Japanese Courses and Teaching Reform," Nihongo No Gakushu To Kenkyu,vol.3,pp.6771,2011 